\title{
Précis knihy Jaké to je, nebo o čem to je? Místo vědomí v ma- teriálním světě
}

\author{
Tomáš Hř́ibek \\ Filosofický ústav \\ Akademie věd České Republiky \\ Jilská 1, 110 oo Praha 1 \\ hribek@flu.cas.cz
}

Článek sumarizuje obsah mé nedávno vydané knihy Jaké to je, nebo o čem to je? Místo vědomí v materiálním světě (2017). Jak napovídá podtitul, tématem knihy je filosofie vědomí. V současné literatuře má většina účastníků na mysli tzv. fenomenální charaktery, přičemž hlavní spor se vede mezi dualisty a materialisty o to, zda jsou to materiální vlastnosti. Dokonce i russelliánští monisté, kteří se jinak prezentují jako alternativa vioči dualismu i materialismu, akceptují pojem fenomenálního charakteru. Já mám o tomto pojmu pochybnosti, jež vyjadřuji v šesté kapitole knihy, jíž proto v článku věnuji nejvíce místa. Navzdory většinovému mínění mám za to, že ohledně obsahu pojmu fenomenálního charakteru ve skutečnosti nebylo dosaženo žádné shody. Podobně jako Daniel Dennett, tudíž doporučuji pokusit se o filosofii vědomí bez pojmu fenomenálního charakteru. Jak známo, Dennett - do jisté míry podobně jako někteří výše zmínění materialisté - navrhuje redukovat vědomí prostřednictvím pojmu reprezentace. Já však končím o poznání skeptičtěji než Dennett, protože v návaznosti na svou předchozí knihu Metafyzika antiindividualismu (2008) soudím, že naturalistická teorie reprezentace je nekoherentní.

Jsem vděčný za pozvání Fỉlosofie dnes stručně představit svou nedávno vydanou monografii o filosofii vědomí, stejně jako kolegům, kteří věnovali čas a úsilí její četbě. Jejich komentáře a námitky pomohou nejen mně, ale i dalším zájemcům o toto téma v českém filosofickém prostředí. V textu, který následuje, ovšem překračuji vlastní obsah knihy v tom směru, že se jednak již snažím anticipovat některé námitky, a jednak poukázat na některá z dílčích témat, kterých jsem se sice v knize již dotkl, ale rád bych se jim věnoval podrobněji v další práci. 


\section{Konceptuální mapa}

Kniha je mimo jiné míněna jako úvod do současné filosofie vědomí, protože český text, který by podrobněji zmapoval dnešní světovou diskusi - a tím mám na mysli zvláště diskusi, jež se odehrála během posledního čtvrtstoletí -, zde dosud chyběl. Ovšem i můj text je pochopitelně selektivní a odráží autorské preference. Mojí preferencí je materialismus, takže prvních pět ze sedmi kapitol knihy věnuji prezentaci materialistických odpovědí novodobým dualistům, a to zvláště těch, jež redukují vědomí prostřednictvím reprezentačních, funkcionálních, a konečně kauzálních pojmů. Nejdelší - šestá - kapitola, o níž ještě bude řeč níže, nabízí, kromě pokusu jistým způsobem rozšriřit známý Dennettův argument proti kváliím, i systematické shrnutí a vysvětlení Dennettova alternativního programu na poli filosofie vědomí. Pokud tedy jde o prezentaci současné scény, lze ji podle mého mínění zachytit následující tabulkou: ${ }^{1}$

\begin{tabular}{|c|c|c|c|c|}
\hline & Dualismus & \multicolumn{2}{|c|}{ materialismus } \\
\hline \multirow{2}{*}{ Fenomenismus } & $\begin{array}{c}\text { Chalmers, } \\
\text { Jackson, } \\
\text { Burge }\end{array}$ & \multicolumn{2}{|c|}{ aposteriorní } & apriorní \\
\hline \multirow{2}{*}{$\begin{array}{c}\text { reprezentacioni- } \\
\text { smus }\end{array}$} & Descartes & Block & Lewis \\
\cline { 3 - 5 } & parentismus & trans- & antitrans- \\
parentismus & Dennett, \\
\cline { 3 - 5 } & & Tye, Dretske & Rosenthal & Pereboom \\
\hline
\end{tabular}

V následujícím textu chci mimo jiné vysvětlit význam termínů, které používám v tabulce. Předtím bych však ještě rád podal odpověd’ na možnou námitku těch čtenářů, kteří jsou se situací v současné filosofii vědomí již seznámeni, a v tabulce jim tudíž chybí jedna z nejdynamičtějších současných škol, totiž russelliánský monismus. Je tomu tak proto, že ho považuji spíše za soubor rozličných názorů než za jednotnou alternativu vůči standardnímu dualismu i materialismu. Mimo jiné existují dualistické i materialistické varianty russelliánského monismu. Každopádně této

1 Hříbek (2017, s. 284). 
pozici věnuji v knize třetí kapitolu, ale v tomto článku ji více méně ponechávám stranou. $\mathrm{V}$ češtině jí navíc věnoval monografii kolega Jakub Mihálik.

\section{Dualismus, materialismus a fenomenalita}

Během druhé poloviny 20. století se prosadila představa, že máme co do činění se dvěma základními druhy mentálních stavů či událostí. $\mathrm{Na}$ jedné straně jsou stavy, které nějakým způsobem představují svět; na straně druhé jsou stavy, jejichž povaha nespočivá v tom - alespoň ne v první řadě, nebo na první pohled -, že by něco reprezentovaly, nýbrž spíše v jejich specifické kvalitě. Tradiční technický pojem intencionality, jímž ještě Husserl charakterizoval všechny stavy mysli, rezervovali pozdější filosofové pro reprezentační stránku mentality, kdežto pro kvalitativní mysl začali konzistentně používat pojem fenomenality. To jsou však technické výrazy; pokud jde o každodenní slovník, pojem myšlení byl vyhrazen pro reprezentační stavy, kdežto rozsah pojmu vědomí byl zúžen na stavy kvalitativní. Mnoho autorů spojuje technický a lidový pojem a hovoří o fenomenálním vědomí. Oba druhy mentálních stavi̊ se navíc vyznačují určitým typem obsahu. Avšak zatímco obsah myšlenek lze snadno vyjádřit propozicí, obsah vědomých stavů je postižitelný mnohem obtížněji. Obsah Petrovy myšlenky, že v šálku je čerstvě uvařená káva, je díky svému propozičnímu charakteru snadno identifikovatelný. Ale jak vyjádřit kvalitu Petrova vědomí odéru čerstvé kávy? Thomas Nagel v sedmdesátých letech prosadil idiom, že zakoušet určitý vědomý stav znamená pro daný subjekt, že to pro něj „nějaké je“, tento stav podstupovat. Zakoušet odér čerstvé kávy je jistě poněkud jiné, než cítit bolest nebo mít vizuální zkušenost červeného rajčete. Mnoha čtenářum Nagelova článku, včetně autora těchto řádků, ovšem připadal jeho idiom př́liš vágní na to, aby s jeho pomocí bylo možné budovat nějakou teorii. Donald Davidson zašel až tak daleko, že vyjádřil pochybnost, zda je fenomenalita vủbec součástí teorie mysli. Většina ostatních se spokojila s méně radikálním závěrem, že teorii myšlení a teorii vědomí lze navzájem oddělit, což jim umožnilo věnovat se té první na úkor druhé. Většina těchto filosofů byli materialisté, kteří v otázce propoziční mysli přijali nějakou verzi funkcionalismu, a o vědomí soudili, že i ono musí nějak 
zapadat do materiálního světa, ačkoli kromě několika jednotlivců (např. Ned Block) se tomuto tématu systematicky věnoval málokdo.

Situace se změnila v devadesátých letech, zvláště od vydání knihy Davida Chalmerse The Conscious Mind ${ }^{2}$, ačkoli pro pozdější diskusi byly podstatné i eseje Franka Jacksona, publikované již v osmdesátých letech. Chalmers a Jackson totiž formulovali dva typy argumentů, z nichž každý otřásl jistotou materialistů. A ačkoli varianty těchto dualistických argumentů najdeme již u Descarta, Leibnize a dalších filosofů, v současné diskusi figurují především ve formě navržené Chalmersem a Jacksonem. Převážná část produkce v současné filosofii vědomí sestává z odpovědí na tyto důmyslné argumenty. Díky nim je dnes situace ve filosofii v podstatě opakem té před třiceti lety, nebot' o vědomí se hovoří mnohem více, než o intencionalitě. Chalmersův argument můžeme nazvat „modální, protože operuje $\mathrm{s}$ děním $\mathrm{v}$ jiném možném světě - v takovém, ve kterém se vyskytuje můj dokonalý fyzický, funkcionální atd. duplikát, jenž však postrádá mé fenomenální kvality. Takový duplikát je tedy tzv. fenomenální zombie. Chalmers shrnuje svi̊j modální argument obvykle následovně: ${ }^{3}$

(1) Fenomenální zombie jsou myslitelné.

(2) Jestliže jsou fenomenální zombie myslitelné, pak jsou metafyzicky možné.

(3) Jsou-li fenomenální zombie metafyzicky možné, pak materialismus neplatí.

$\therefore \quad$ Materialismus neplatí.

Rovněž Jackson pracuje s jistým myšlenkovým experimentem: máme si představit talentovanou neurovědkyni Marii, jež strávila celý svůj dosavadní život v černobílé laboratoři, a konečně se dostala na svobodu. Jackson tvrdí, že navzdory své úplné znalosti neurofyziologie barevného vnímání se Marie během svého prvního výletu dozví něco nového, totiž jaké to je vidět zelenou trávu, červené rajče atd. To znamená, že znalost barev nelze vyvodit z úplné fyzikální teorie barev. Ergo, materialismus není kompletní popis světa. Pro tento argument jsou klíčové

2 Chalmers (1996).

3 Hř́ibek (2017, s. 77). 
úvahy o poznání, takže ho nazývám „epistemický“. Schematicky ho lze znázornit takto:4

(1) Některé pravdy o vědomí nejsou dedukovatelné z úplné fyzikální pravdy, totiž ty pravdy, které se Marie dozví, jakmile opustí svou černobílou místnost.

(2) Jestliže existují pravdy o vědomí, které nejsou dedukovatelné z úplné fyzikální pravdy, pak existují pravdy o vědomí, které nejsou nutným důsledkem fyzikální pravdy.

(3) Jestliže existují pravdy o vědomí, které nejsou nutným důsledkem fyzikální pravdy, materialismus neplatí.

$\therefore \quad$ Materialismus neplatí.

Je fakt, že Chalmers hovoří o vlastnostech, kdežto Jackson o fenomenálních pravdách. Chalmers dokazuje, že zmíněné vlastnosti jsou odlišné od fyzikálních vlastností, zatímco Jackson tvrdí, že fenomenální pravdy nevyplývají z fyzikálních pravd. V knize se kloním k Chalmersovu idiomu fenomenálních vlastností, resp. fenomenálních charakterů, nebot’ v první kapitole definuji i materialismus z hlediska vlastností - spíše než, řekněme, z hlediska jednotlivin - jakožto tezi, že fenomenální vlastnosti jsou fyzikální vlastnosti. $V$ téže kapitole odpovídám i na další dvě otázky, které vyvstávají v kontextu definice materialismu: Co jsou fyzikální vlastnosti? (Odpověd': jsou vyjádřeny predikáty prŕitomné, spíše než budoucí fyzikální teorie.) Jaký je vztah mezi mentálními a fyzikálními vlastnostmi? (Odpověd': globální supervenience).

Až ve čtvrté kapitole však předkládám důkaz materialismu, a to prostřednictvím standardního tzv. kauzálního argumentu, jak ho během posledních zhruba dvaceti let formuloval zvláště Jaegwon Kim: ${ }^{5}$

(1) Některé fenomenální události mají fyzické důsledky.

(2) Všechny fyzické důsledky mají čistě fyzické př́íčiny.

(3) Fyzické důsledky fenomenálních událostí nemají žádné dodatečné příčiny.

$\therefore \quad$ Fenomenální události jsou fyzické události.

4 Tamtéž, s. 90.

5 Tamtéž, s. 135. 
První premisa tohoto argumentu konstatuje mentální kauzalitu, tj. fakt kauzálního vlivu fenomenálních událostí v materiálním světě. Třetí premisa vyjadřuje tzv. princip kauzální exkluzivity, což je obecný metafyzický princip. Jaký status má však druhá premisa, jež vyjadřuje tzv. princip kauzální uzávěry fyzična? Kloním se k názoru Davida Papineaua, že jde o aposteriorní tezi, jejíž pravděpodobnost podporuje pokrok vědy od jejích počátků v 17. století do současnosti. Budeme-li tedy předpokládat, že materialismus je velmi plauzibilní vysoce obecná hypotéza, jak si tato hypotéza poradí s Chalmersovým a Jacksonovým argumentem?

Platí-li materialismus, pak mezi fenomenálními a fyzikálními vlastnostmi nezeje ontologická mezera. Avšak většina materialistů zároveň akceptuje první premisy modálního a epistemického argumentu: připouštějí tedy, že fenomenální zombie jsou myslitelné a že existují fenomenální pravdy, jež nelze dedukovat z totální fyzikální pravdy. A to znamená, že tito autoři připouštějí existenci nikoli sice ontologické, ale epistemické mezery: ${ }^{6}$

Epistemická mezera. Fenomenální poznatky nelze a priori vyvodit z fyzikálních poznatků.

Podle zastánců této teze je epistemická mezera důsledkem faktu, že pro popis našich vědomých stavů ze subjektivního hlediska máme $\mathrm{k}$ dispozici speciální druh pojmů - tzv. fenomenální pojmy. Tyto pojmy sémanticky fungují jako demonstrativa, jejichž referentem jsou sice fyzikální, nejspíš cerebrální stavy - čímž je garantován materialismus -, ale tyto události jsou popisovány fenomenologickým slovníkem - který vyjadřuje, jaké to subjektivně je, nacházet se v takových stavech. Z mnoha variant tohoto př́stupu zmiňuji typovou variantu (Brian Loar, Ned Block) - kdy referentem fenomenálních pojmů jsou druhy či typy zkušeností, jak jsou dostupné ze subjektivního hlediska - a instanční variantu (Michael Tye) - kdy referentem takových pojmů jsou konkrétní instance nějaké zkušenosti. Stojí za to zmínit, že tato strategie hraje důležitou roli i v mém argumentu v šesté kapitole. Kromě strategie fenomenálních pojmů však hovořím i o návrzích filosofư jako Paul Churchland, David Lewis a Dennett, kteří existenci epistemické mezery popírají. Např́íklad Dennett komentuje případ neurovědkyně Marie v tom smyslu, že si

6 Tamtéž, s. 140. 
mohla odvodit znalost barev již ze své znalosti kompletní fyzikální teorie. Jinými slovy, Dennett není ochoten - na rozdíl od většiny současných materialistů - připustit pravdivost ani první premisy Jacksonova argumentu (a týž postoj zastává vůči Chalmersovu argumentu). Tím je již částečně naznačena nekonformnost Dennettova přístupu k vědomí, kterému se věnuji později v knize. V literatuře se obvykle uvádí, že Dennett zastává

apriorní fyzikalismus. Fenomenální pravdy jsou vyvoditelné z fyzikálních pravd.

Naopak ti materialisté, kteří popírají možnost takové inference a věří ve strategii fenomenálních pojmů, zastávají

aposteriorní materialismus. Fenomenální pravdy nejsou a priori vyvoditelné z fyzikálních pravd.7

Uvedené strategie, jimiž standardní i nestandardní materialisté reagují na Chalmersův a Jacksonův argument, je však třeba doplnit rozborem pozitivních teorií vědomí, s nimiž materialisté přišli. V páté kapitole proto analyzuji názory autorů, jako jsou Tye, Peter Carruthers či David Rosenthal, kteří sdílejí naději, že fenomenální vědomí lze redukovat prostřednictvím pojmu reprezentace, a posléze funkce a kauzality. Tito autoři tedy zastávají

reprezentacionismus. Fenomenální vlastnosti supervenují

na reprezentačních vlastnostech. ${ }^{8}$

Podrobněji komentuji několik reprezentacionistických teorií, které se navzájem liší jednak tím, kolik úrovní reprezentace zavádějí, a jednak tím, zda považují za prostředek takové reprezentace myšlenky nebo vjemy. Např́lklad Michal Tye vypracoval verzi reprezentacionismu prvního řádu, podle níž jsou i takové stavy, jež bývaly tradičně považovány za výlučně fenomenální - např́iklad vizuální zkušenosti nebo i bolesti -, chápány jako reprezentace stavů světa nebo vlastního těla. Naopak David Rosenthal přišel s variantou reprezentacionismu vyššího řádu, která postuluje dva stavy: první, který reprezentuje nějaký stav světa či těla; a druhý, vyšší stav (myšlenku), reprezentující první, nižší stav. Mezi těmito variantami reprezentacionismu dochází $\mathrm{k}$ zajímavým sporům

7 Tamtéž, s. 142.

8 Tamtéž, s. 180. 
například ohledně animálního vědomí (stoupenci reprezentacionismu vyššího řádu mají s takovým vědomím problém, protože většina zvířat zřejmě nemá sofistikované myšlenky), které analyzuji v pátém oddíle páté kapitoly. Kromě toho se v literatuře vynořily spory mezi reprezentacionismem a tzv. fenomenismem, což je teorie popírající redukovatelnost fenomenálního vědomí prostřednictvím reprezentace. Definujme ji následovně:

Fenomenismus. Intencionální obsah supervenuje na fenomenálním obsahu. ${ }^{9}$

Tento pojem zavedl Block a hraje roli ve sporu o tzv. fenomenální externalismus, což je teze o povaze fenomenálních stavů, podle níž jsou takové stavy široké, tj. závislé na charakteru vnějšího prostředí. Tato teze je import z teorie intencionality, vlivné zvláště v sedmdesátých až devadesátých letech. Pokud někdo redukuje fenomenalitu na intencionalitu, zdá se, že se zavazuje i vưči fenomenálnímu externalismu, což Block považuje za reductio ad absurdum reprezentacionismu. Reprezentacionisté jako Michael Tye či Fred Dretske však mají jiný názor. Jejich pojem fenomenality je však nakonec tak subtilní, že se táži, nelze-li předmět demonstrativní reference při subjektivním popisu zkušenosti popsat čistě fyzikalisticky. Tím se otevírá prostor pro teorií vědomí bez fenomenálního charakteru, jíž se věnuji ve zbytku knihy.

\section{Vědomí bez fenomenálního charakteru}

Tato alternativní teorie, jejímž hlavním představitelem je Daniel Dennett, sice sdílí některé styčné body se standardním materialismem, ale zároveň se od něj významně liší. Mimo jiné tyto shody a rozdíly vysvětluji ve zbytku knihy, přičemž nakonec naznačuji i jistou překážku naturalismu, který podle mého názoru dosud ignoroval i Dennett.

Pokud jde o předpoklad, který podle mého názoru sdílejí nejen standardní materialisté, ale koneckonců i dualisté, russelliánští monisté a vlastně téměř všichni hráči v rámci současné filosofie vědomí, mám na mysli tezi, že předmětem této filosofie je fenomenální charakter. Tento

9 Tamtéž, s. 181. 
aspekt vědomí je tím, co představuje výzvu pro materialismus a s čím si materialisté různých barev pokoušejí poradit, resp. o čem se dualisté domnívají, že si s tím poradit nelze, aniž materialismus odmítneme. Je však skutečně zřejmé, že pojem fenomenálního charakteru má jasný obsah, na němž se všichni účastníci debaty shodují? Klíčový argument knihy má ukázat, že nikoli. Jedná se o jistou extenzi Dennettova známého argumentu proti kváliím v jeho článku „Quining Qualia“10. Připomeňme si, že starší filosofie označovala výrazem „kvália“ jisté enigmatické rysy vědomí, mezi nimiž byly obvykle zmiňovány tyto: ${ }^{11}$

1. niternost: jde o rysy, jež jsou neoddělitelné od zkušenosti a v principu nepř́ístupné analýze;

2. nepopsatelnost: subjekt kválií nemůže druhým sdělit, jak přesně zakouší svět, případně své vlastní stavy;

3. privátnost či subjektivita: na rozdíl od objektivních vlastností, jež jsou dostupné všem, a tudíž i vědeckému zkoumání, kvália jsou př́ístupná svému subjektu;

4. nekorigovatelnost: zatímco objektivní popis může být více nebo méně správný a lze ho případně opravovat, kvália jsou bezprostředně zjevná subjektu.

Dennettův výraz „quineace“ chápu jako synonymum „eliminace“ - entity, které quinujeme, vyřazujeme z naší ontologie, a tudíž eliminujeme. Tento záměr však není z textu „Quining Qualia“ na první pohled jasný, nebot’ Dennett nenabízí - což je pro něj mimochodem typické - přímočarý argument, nýbrž spíše soubor analogií a myšlenkových experimentů. Jejich účelem není mást čtenáře, nýbrž naopak osvobodit jeho mysl od jistých pojmových předpokladů a schémat, jež nám vnucují mnohé zdánlivě přímočařejší výklady. Klíčový předpoklad, o jehož zřejmosti nás chce Dennett přimět pochybovat, je teze, že každý z našich vědomých stavů má zcela určitý obsah, a zvláště že každý z nás coby subjekt svých vědomých stavů, je výlučně schopen tyto obsahy identifikovat. Jak jsem

\footnotetext{
10 Dennett (1988).

11 Hř́bek (2017, s. 221).
} 
již zmínil, Dennett sám považuje za spíše matoucí vyjádřit svůj záměr tímto teoretickým způsobem. Přesto navrhuji vyjádřit tvar Dennettovy úvahy prostřednictvím následujícího schématu: ${ }^{12}$

(1) Kvália existují, pokud je naše vědomá zkušenost specifickým způsobem (resp. specifickými způsoby) sama o sobě.

(2) Ale naše vědomá zkušenost není specifickým způsobem (resp. způsoby) sama o sobě.

$\therefore \quad$ Kvália neexistují.

Je pozoruhodné, že v textech materialistů, které se objevily během uplynulých tří dekád, najdeme značnou shodu v názoru na význam a platnost Dennettovy kritiky kválií. Tito autoři, přestože mezi sebou kromě své základní materialistické orientace $\mathrm{v}$ mnoha ohledech nesouhlasí, se shodují na tom, že Dennettovi je sice třeba pogratulovat za užitečnou demoliční práci, díky níž se současní materialisté již nemusejí potýkat s naturalizací natolik nezdolných entit, jakými jsou kvália - ale zároveň je třeba připustit existenci vlastností, které Dennett svou kritikou nezasáhl a jež jsou tím skutečným cílovým fenoménem naturalizačního programu. Těmito vlastnostmi jsou pochopitelně kvalitativní vlastnosti, resp. fenomenální charaktery. V knize cituji výmluvné pasáže z textů Owena Flanagana, Michaela Tye, Petera Carrutherse, Neda Blocka i českých kolegů Tomáše Marvana a Michala Poláka, které v různých obměnách tuto základní myšlenku sdílejí: Dennett osvobodil současnou filosofii vědomí od kválií, ale nemohl samozřejmě eliminovat fenomenální charaktery. Já v knize navrhuji rozšśřit Dennettův argument proti kváliím takovým způsobem, že zasáhne i pojem fenomenálních vlastností. Uvažuji zhruba následovně. Tradiční kvália, kterým byly připisovány výše jmenované čtyři vlastnosti, jsou inflační kvália. Filosofové, kteří souhlasí s Dennettovou demolicí inflačních kválií, nicméně věří na jakási deflační kvália, která sice postrádají ony čtyři problematické vlastnosti, avšak přesto charakterizují, jaké to je, podstupovat vědomou zkušenost. Zde je však na místě otázka, zda po eliminaci inflačních kválií zbývá pojmu deflačních kválií, tj. fenomenálních charakterů, nějaký obsah. Jak bychom to mohli

12 Tamtéž, s. 222. 
zjistit? Podle mého názoru máme k dispozici nejméně dvě metody. První z nich nabízejí Chalmersovy a Jacksonovy myšlenkové experimenty. Deflační kvália jsou pak právě ty vlastnosti, které má Chalmers, ale nikoli jeho zombijský duplikát; resp. ty vlastnosti, o nichž Marie uvnitř své laboratoře nic netuší. Jenže pokud budeme souhlasit, že tyto vlastnosti nemají čtyři mysteriózní rysy tradičních inflačních kválií, není důvod, proč bychom zmíněné reziduální vlastnosti nemohli interpretovat fyzikalisticky. Druhou metodu, jak dodat nějaký obsah deflačním kváliím, čili fenomenálním vlastnostem, poskytuje demonstrativní strategie intepretace fenomenálních pojmů, o níž jsem se zmínil v předchozím oddíle. Nemohou být deflační kvália nakonec referenty demonstrativních gest? Tento návrh vypadá slibně, ale bohužel se vzápětí ukazuje, že neexistuje žádná shoda na tom, co přesně je referentem takových gest. Například Tye má za to, že jsou to vlastnosti materiálních věcí (jeho pojetí zkušenosti je tedy transparentní), kdežto Rosenthal se domnívá, že jsou to vlastnosti zkušeností (jeho pojetí je tedy antitransparentní). Jak se tedy ukazuje, navzdory názoru mnoha filosofư vědomí, že bylo přinejmenším dosaženo shody na tom, co je předmětem vysvětlení - tj. fenomenální vlastnosti -, žádná taková shoda ve skutečnosti neexistuje. Schéma mého argumentu proti fenomenálním charakterům pak vypadá souhrnně takto: ${ }^{13}$

(1) Ačkoli neexistují inflační kvália, existují deflační kvália, tj. fenomenální vlastnosti.

(2) Fenomenální vlastnosti jsou bud' (a) vlastnosti, izolované prostřednictvím myšlenkových experimentů, nebo (b) vlastnosti, jež jsou referenty introspektivní demonstrace.

(3) Ale fenomenální vlastnosti nemohou být (a), protože to mohou být regulérní fyzikální vlastnosti, které nás pouze disponují k tomu, abychom je popisovali jako kvalitativní. A fenomenální vlastnosti nemohou být (b), protože neexistuje žádná shoda na tom, co je předmětem introspektivní reprezentace.

$\therefore$ Deflační kvália, resp. fenomenální vlastnosti, neexistují. 
Již v knize ochotně připouštím, že tento argument není deduktivně platný. Obhájce fenomenálních charakterů totiž může namítnout, že neúspěch dosavadních pokusů dodat tomuto pojmu obsah nevylučuje zdar budoucích návrhů. To uznávám, ale zároveň mám za to, že v tomto směru již bylo vynaloženo tolik úsilí, že je čím dál tím nepravděpodobnější, že se na tomto poli dočkáme průlomu. Znamená to, že projekt filosofie vědomí jako takový je bez obsahu či nekoherentní? Ne nutně. Existují přece pokusy vybudovat filosofii vědomí, či přesněji řečeno projekt naturalizované teorie vědomí, na úplně jiných základech. Patrně nejznámějším takovým projektem je ten Dennettův, jehož výkladu se tudíž věnuji ve zbytku šesté kapitoly.

Můj výklad se soustřed’uje na dvě základní komponenty Dennettovy alternativní teorie, jak ji předložil zvláště v Consciousness Explained:14 teorii paralelních náčrtů a teorii joyceovského stroje. Podle první teorie nemají stavy vědomí, navzdory mínění většiny filosofů, žádné definitivní kontury a podle druhé teorie je subjektivní proud vědomí výsledkem užití jazyka při samomluvě. Podstatné je, že vědomé stavy mají mnohem více charakter jazykově strukturovaných soudů, než čistě fenomenálních zdánlivostí. V souvislosti s mou interpretací Dennettovy teorie se chci zmínit o třech spornějších tezích, které v knize hájím. První z nich se týká Dennettova údajného fenomenálního antirealismu či eliminativismu. Prominentní filosofové jako Block, Chalmers i John Searle tvrdí, že Dennett popírá samu existenci vědomí. Ve druhé sekci šesté kapitoly tuto tezi vyvracím pomocí argumentace z Dennettovy nejnovější knihy From Bacteria to Bach and Back ${ }^{15}$, z níž podle mého mínění plyne dostatečně jasně, že Dennett považuje vědomé stavy za konkrétní stavy mozku. Dennett je tedy, co se týče vědomí, materialistickým realistou. Je ovšem možné, že v této otázce nadále přetrvává nedorozumění. Pokud autor knihy From Bacteria to Bach and Back popírá fenomenalitu vědomí, co z vědomí zbývá? Pokud se vědomí vyčerpává fenomenalitou, nejsou cerebrální stavy, které Dennett nabízí pro identifikaci se stavy vědomí, čistě fyzikální? Vypadá to skutečně jako eliminativismus: vědomí našlo své místo v materiálním světě - přesněji řečeno v mozku - tak, že

14 Dennett (1991).

15 Dennett (2017). 
byla popřena jeho existence. Na tomto místě bych rád text knihy doplnil připomínkou Chalmersova argumentu z jeho článku „Facing Up to the Problem of Consciousness“"16, který tolik ovlivnil celkový rozvrh filosofie vědomí během posledního čtvrtstoletí. Chalmers rozlišil celou řadu témat, která obvykle zahrnujeme pod rubriku „vědomí“ - pozornost, vnímání, pamět, atd. A sám Chalmers ochotně připouští, že všechny tyto typy vědomých fenoménů lze naturalizovat pomocí funkcionálního a kauzálního instrumentária. Pouze fenomenální aspekt vědomí naturalizaci uniká, čímž Chalmers de facto formuloval výzvu, kterou v následujícím období přijali standardní materialisté. Tento rozvrh je však podstatný i pro správné pochopení Dennettovy pozice. Chalmers a Dennett souhlasí vlastně téměř ve všem - pozornost, vnímání atd. jsou tématy naturalizované teorie vědomí. Jeden od druhého se liší pouze v názoru na údajný fenomenální aspekt vědomí. Chalmers má za to, že jde o esenciální rys vědomí, s nímž stojí a padá osud materialismu. Dennett se naopak domnívá, že tento údajně podstatný rys vědomí je iluzorní, což můžeme interpretovat tak, že pojmu fenomenálního charakteru se nepodařilo dát specifický obsah, takže bychom se ho měli vzdát. Ještě jinak řečeno: můžeme eliminovat fenomenalitu, ale to neznamená, že bychom museli eliminovat vědomí, nebot’ všechny ostatní typy mentálních událostí, jež tradičně klasifikujeme jako vědomé (pozornost, vnímání atd.), jsou zachovány - a právě ty bychom snad mohli naturalizovat. (Ale viz oddíl 4 níže.)

Zbývající dvě ze tří spornějších témat Dennettova přístupu k vědomí, která jsem chtěl zmínit, se týkají vztahu mezi vědomím a intencionalitou a mezi Dennettovou teorií a reprezentacionismem. Jak známo, Dennett vypracoval teorii intencionálních postojů, která mu vynesla obvinění z intencionálního antirealismu, resp. instrumentalismu, které si částečně vysloužil několika neopatrnými vyjádřeními. V pozdějších pracích se pokusil uvést tato vyjádření na pravou míru, když tvrdil, že myšlenky sice nejsou nějaké cerebrální události, ale nejsou to ani fikce. Jsou to popisy struktur postřehnutelných z té správné perspektivy - z perspektivy intencionálního postoje - v chování. Znamená to tedy, že podle Dennetta jsou myšlenky struktury chování, kdežto vědomé stavy události v mozku? Ve skutečnosti je mezi nimi souvislost užší, než naznačuje tento zá-

16 Chalmers (1995). 
věr. Subjekty se mýlí ohledně charakteru svých zkušeností - např́iklad je považují za obrazy, ačkoli mají spíše povahu soudů. Je tedy Dennett přece jen fenomenálním antirealistou, nebot popírá zdánlivosti a připouští jen neuronální vzruchy? Nikoliv, protože podle teorie paralelních náčrtů jsou i soudy svého druhu zdánlivosti, nebot podléhají neustálým korekcím. Tím se dostáváme k otázce vztahu mezi Dennettem a reprezentacionisty. Je Dennett - ve světle toho, co bylo právě řečeno - fakticky jedním z nich? Ne, protože reprezentacionisté jako Tye a Carruthers rozlišují mezi tím, jak věci zakoušíme, a tím, co o své zkušenosti sdělujeme. Dennett naopak odmítá, že by fakta o vědomí měla nějaké jasné kontury nezávislé na otázkách, jež subjektu zkušenosti adresujeme.

\section{Jaký druh naturalismu?}

V sedmé, závěrečné kapitole knihy mi jde o dvě hlavní věci: o metafilosofickou charakteristiku Dennettova projektu a o formulaci skeptické pozice, kterou vi̊či filosofii vědomí zastávám. Pokud jde o první úkol, domnívám se, že Dennetta nemůžeme klasifikovat, jak to dělá např́íklad Chalmers v The Conscious Mind, jako eliminativního materialistu. Pro Dennetta je mnohem více než materialistická metafyzika podstatná naturalistická metodologie. To je patrné např́klad v úvodu k jeho sbírce esejí The Intentional Stance ${ }^{17}$, v němž Dennett polemizuje s Nagelem. Celý argument lze číst jako spor o pokoře. Nagel věrí, že nikdy nezjistíme, jaké to je, být netopýrem - což znamená, že nikdy nebudeme mít materialistickou teorii vědomí -, a prezentuje se tudíž jako vzor metafyzické pokory, přičemž Dennetta vykresluje jako příklad vědecké domýšlivosti. Dennettova úvaha je mimo jiné obdivuhodná tím, jak dokáže obrátit totéž obvinění proti svému oponentovi. Nagel předčasně abdikuje na standardní vědeckou metodu, aniž by pokorně zjistil, co vše nám již umožnila zjistit o psychologii netopýrů. Naopak Dennett doporučuje nahradit grandiózní metafyzická prohlášení trpělivou vědeckou prací. Dennett, nikoli Nagel, je tedy př́kladem metafyzické pokory. Obecně platí, že Dennett nepostupuje jako standardní eliminativní materialista, jenž si definoval, v jakém smyslu je svět materiální, a když je pak kon-

17 Dennett (1987). 
frontován s problémem místa fenomenálních a jiných problematických vlastností v takovém obrazu světa, rozhodne se je eliminovat. Na rozdíl od některých radikálních kolegů nás Dennett nemíní připravit o manifestni obraz na úkor vědeckého obrazu světa. Pokud jde speciálně o kvália či fenomenální charaktery, stojí za povšimnutí dvě věci. Za prvé, jde o filosofické konstrukce. A za druhé, dennettovská eliminace je výsledkem aplikace standardních vědeckých postupů v kombinaci s myšlenkovými experimenty, jež známe i z vědeckého výzkumu. Dennett je tedy naturalistický materialista v tom smyslu, že odmítá existenci okultních vlastností a entit - ale ty odmítá nikoli prostředky apriorní filosofické argumentace, nýbrž proto, že nehrají roli ve standardním empirickém zkoumání.

Druhý úkol sedmé kapitoly je zdůvodnit můj skeptický postoj vůči filosofii vědomí. Již ve druhém oddíle této studie jsem zmínil svou dlouholetou nedůvěru k etablovaným způsobům hovoru o fenomenálním vědomí, jež mají svůj původ patrně u Nagela, ale to není to, co mám zde na mysli. Myslím, že skepse je na místě i vưči alternativnímu projektu, jako je ten Dennettův, pokud jej budeme chápat jako návrh redukovat vědomí prostřednictvím reprezentačních pojmů. Ve své starší knize, Metafyzika antiindividualismu ${ }^{18}$, jsem totiž došel k závěru, že teorie propoziční mysli je svým způsobem nekoherentní, protože se snaží spojit několik vzájemně rozporných závazků. (Tento argument je výsledkem analýzy metafyzických důsledků tzv. psychologického antiindividualismu či externalismu, který byl populární v osmdesátých až devadesátých letech minulého století.) Je-li tedy v úzkých teorie reprezentace, je v úzkých i teorie vědomí, která se snaží vědomí redukovat na reprezentaci. $Z$ toho důvodu se mi situace jeví problematičtější, než jak připadala Chalmersovi v jeho článku z roku 1995, v němž formuloval

těžký problém vědomí. Proč je neurofyziologický proces doprovázen danou fenomenální vlastností? ${ }^{19}$

Chalmers sice nepovažoval za slibnou naturalizaci fenomenálního vědomí, ale v otázce intencionality byl mnohem větším optimistou, nebot’ zde

18 Hříbek (2008).

19 Hříbek (2017, s. 68, 294). 
- jako mnoho jiných filosofů - v podstatě akceptoval funkcionalismus. Já jsem skeptický i v této oblasti, takže formuluji

nejtěžší problém vědomí. Náš intencionální diskurs je možná pseudodiskurs. A má-li tento diskurs být základem pro naturalizaci vědomí, pak jde o pochybný základ?²0

\section{Dezideráta}

Závěrem bych rád zmínil několik témat, která jsou v knize bud’ nedopracovaná, nebo jsem je vypustil kvưli rozsahu a dodržení termínu, ale tak jako tak by si zasloužila doplnění formou samostatných studií. Ačkoli se věnuji téměř výlučně literatuře $\mathrm{z}$ anglofonního analytického prostředí, nebot' v něm se diskuse o fenomenálním vědomí během posledních tř́ dekád především odehrávala, nemohl jsem se v publikaci, určené českému čtenáři, vyhnout fenomenologickému pojetí vědomí, nebot' fenomenologická filosofie - zvláště v díle jejího zakladatele Edmunda $\mathrm{Hu}$ sserla - je v našem prostředí dosud velmi vlivná. V knize vysvětluji, že husserlovské pojetí vědomí má v analytické tradici zjevné paralely, zvláště ve funkcionalismu šedesátých a osmdesátých let. Teprve po publikaci Jaké to je, nebo o čem to je? mi však došlo, že Husserl má právě z tohoto důvodu málo společného se současným tématem fenomenálního vědomí. Pro Husserla je vědomí vysvětlitelné funkcionalisticky. Detaily této hypotézy bych rád co nejdřive prozkoumal. Další více méně historické téma se týká vztahu jiného moravského rodáka, Ernsta Macha, k současnému russelliánskému monismu. K tomuto tématu jsem mezitím napsal krátkou kapitolu do jiné knihy, ${ }^{21}$ ale otázka, do jaké míry je machovský monismus podobný russelliánskému monismu, či spíše od něj odlišný, vyžaduje další výzkum.

Pokud jde o aktuální témata, v knize absentuje téma tzv. kognitivní fenomenologie. Během posledních let se objevila řada publikací, které zkoumají fenomenologii myšlenek a jiných reprezentačních stavů, čímž vlastně zpochybňují striktní cézuru mezi intencionalitou a fenomenali-

20 Tamtéž, s. 304.

21 Viz Hř́ibek (2018). 
tou, z níž v knize vycházím (a kterou zmiňuji i na začátku druhého oddílu této studie). Některé výsledky kognitivní fenomenologie zatím sleduji s nedůvěrou, ale každopádně je třeba se jim věnovat. Dalším živým tématem, zvláště mezi evolučně orientovanými autory, mezi něž patř́i i Dennett, je biologický smysl či účel vědomí. Zmiňuji se o něm v posledním oddíle šesté kapitoly, avšak z důvodu proporcionality jsem nezařadil další materiál, který jsem měl připravený. Použiji ho při jiné př́ležitosti. V knize rovněž okrajově zmiňuji teorii vědomí Tylera Burge - zvláště v posledním oddíle páté kapitoly o fenomenálním externalismu. Burge je velmi známý jako proponent externalismu coby teorie o povaze reprezentačních stavi̊, ale jeho internalistické pojetí vědomí vzbudilo, pokud vím, mnohem méně pozornosti. Rád bych mu proto věnoval samostatnou studii. A možná nejdůležitější deziderátum nakonec: Tomáš Marvan mne v době, kdy jsem svou knihu dokončoval, upozornil na práci filosofa Keithe Frankishe, jehož strategii extenze Dennettovy argumentace zjevně sdílím. Avšak teprve několik měsíců po vydání mé knihy vyšel sborník, který obsahuje Frankishův asi nejsystematičtější výklad jeho pozice, následovaný námitkami předních filosofư, včetně Dennetta. ${ }^{22}$ Frankish nazývá svou teorii „iluzionismem“ a dokonce i Dennett, jak známo, hovořil již v Consciousness Explained o „uživatelské iluzi“ (já tento Dennettův obrat cituji ve své knize ${ }^{23}$ ). Jak jsem vysvětlil výše, moje pozice v knize je taková, že „iluzorní“ jsou fenomenální charaktery, coby vlastnosti mylně přisuzované vědomí - avšak nikoli sama vědomá zkušenost. Tuto pozici v knize přisuzuji i Dennettovi, i když ex post musím dodat, že mi záleží spíše na tom, aby tato pozice byla správná, než aby ji podepsal slavný filosof. Každopádně musím nyní spolehlivěji zjistit jednak rozsah a povahu Frankishova iluzionismu, a jednak jak Frankishe interpretuje Dennett.

22 Frankish (2017).

23 Hř́ibek (2017, s. 268). 


\section{Literatura}

Dennett, D. (1987): The Intentional Stance. The MIT Press, Cambridge, Mass.

Dennett, D. (1988): „Quining Qualia.“ In The Nature of Consciousness: Philosophical Debates, eds. N. Block, O. Flanagan \& G. Güzeldere, The MIT Press, Cambridge, Mass, 1997, s. 519-547.

Dennett, D. (1991): Consciousness Explained. Little, Brown, Boston.

Dennett, D. (2017): From Bacteria to Bach and Back: The Evolution of Minds. W. W. Norton \& Co., New York.

Frankish, K., ed. (2017): Illusionism as a Theory of Consciousness. Imprint Academic, Exeter.

Hř́bek, T. (2008): Metafyzika antiindividualismu. Filosofia, Praha.

Hříbek, T. (2017): Jaké to je, nebo o čem to je? Místo vědomí v materiálním světě. Filosofia, Praha.

Hř́bek, T. (2018): „Mach and Panqualityism.“ In Ernst Mach - Life, Work, and Influence, ed. F. Stadler, Springer, Vienna, (v tisku).

Chalmers, D. (1995): „Facing up to the Problem of Consciousness“. Journal of Consciousness Studies 2 (3): 200-219.

Chalmers, D. (1996): The Conscious Mind. Oxford University Press, Oxford.

\section{Abstract}

Précis of What It's Like, or What It's About? The Place of Consciousness in the Material World

The paper provides a summary of my recent Czech-language book, What It's Like, or What It's About? The Place of Consciousness in the Material World (2017). As suggested by the subtitle, the topic of the book is philosophy of consciousness. In the contemporary literature, most participants have in mind the so-called phenomenal characters, and the main issue debated between dualists and materialists is whether these characters are material properties. Even the Russellian monists, 
who otherwise present themselves as an alternative to both dualism and materialism, accept the concept of phenomenal character. I express doubts about this concept in chapter six of my book; accordingly, I allot most space in the paper to the material from this chapter. Despite the majority opinion, I believe that no agreement has in fact been reached concerning the content of this concept. Similarly to Daniel Dennett, I recommend trying to develop a philosophy of consciousness without the concept of phenomenal character. As is well known, Dennett - to some extent similarly to the aforementioned materialists - proposes a reduction of consciousness in terms of representation. However, I wound up rather more skeptical than Dennett, since following up on my previous book, The Metaphysics of Anti-Individualism (2008), I claim that a naturalistic theory of representation is incoherent.

Hř́bek, T. (2017): „Précis knihy Jaké to je, nebo o čem to je? Místo vědomí v materiálním světě." Filosofie dnes 9 (2): 4-22. Dostupné z www.filosofiednes. ff.uhk.cz. 